\title{
ZnOの基本物性と光デバイス応用
}

\author{
藤田 静雄 \\ 京都大学大学院 工学研究科 ( $7615-8520$ 京都市西京区京都大学桂2)
}

\section{Fundamental Properties and Optical Device Applications of $\mathrm{ZnO}$}

\author{
Shizuo FUJITA \\ Graduate School of Engineering, Kyoto University, 2 Kyotodaigaku-katsura, Nishikyo-ku, Kyoto 615-8520
}

(Received October 10, 2010)

\begin{abstract}
Zinc oxide $(\mathrm{ZnO})$ has been recognized as a promising material for ultraviolet optical devices, especially in light emitting diodes (LEDs) and lasers, supported by high exciton binding energy, small lattice mismatches in ( $\mathrm{ZnMgCd}) \mathrm{O}$ alloys, and low cost for materail and fabrication. Recent achievement of a $\mathrm{MgZnO} / \mathrm{ZnO}$ heterojunction LED emitting $382 \mathrm{~nm}$ encourages the future development of a variety of not only optical devices but also electronic devices. This paper reviews the fundamental properties of $\mathrm{ZnO}$ and related materials, emphasizing the application of single crystalline thin films and multilayers for devices. Up-to-date achievements on materials properties, multilayer structures, and p-type doping followed by optical devices are summarized and their future trends are discussed.
\end{abstract}

Key Words: Ultraviolet light emitters, Excitons, Heterostructures, Doping, Functional oxide semiconductors

1. はじめに

酸化亜鉛 $(\mathrm{ZnO})$ からの電子ビーム励起レーザー発振が 見られたのは40年以上前の時代であった年，その後， 半導体結晶成長技術の進展により, 発光ダイオード (light emitting diode; LED) やレーザー等の紫外発光デバ イス材料として注目されるようになり, 早や10年以上を 経た。この間, 全世界的に研究のアクティビティが増 し, 高品質の結晶および多層構造が実現されるに至った ものの, p 型伝導の実現・制御に決め手を欠き, 発光デ バイスの実証に至る最後の段階で足踏み状態というのが 実際のところと言えるのではないだろうか. その中で, 2010年になり, $\mathrm{MgZnO} / \mathrm{ZnO}$ シングルヘテロ構造ダイ オードにおいて, $\mathrm{ZnO}$ のバンド端に近い $382 \mathrm{~nm}$ に単一 ピークを持つ電流注入発光が報告されるに至り ${ }^{3)}$, 今後 の応用への期待が高まってきた，本稿では，単結晶によ る光デバイスへの応用に焦点を当て, $\mathrm{ZnO}$ の基礎的な性 質と物性制御に関して, 従来の研究の流れを概観する。 あわせて，今後のデバイス応用に向けた展望を述べる。

\section{2. $\mathrm{ZnO}$ の基礎物性}

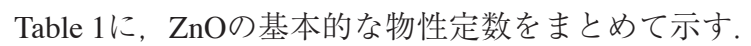
$\mathrm{ZnO}$ の特徵の一つとして, 励起子結合エネルギーが約 $60 \mathrm{meV}$ と大きいことが挙げられる。これは
る $28 \mathrm{meV}$ よ大きい.このことは励起子が安定に存在 すること, かつ光学遷移における振動子強度が大きいこ とを意味する ${ }^{4)}$. 例えば室温で励起子発光が観測される

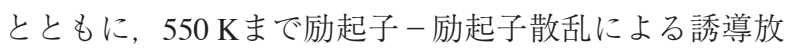
出が観測されている5 $\mathrm{ZnO}$ 薄膜および $\mathrm{MgZnO} / \mathrm{ZnO}$ 超格子から励起子が関与し

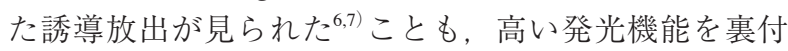
けている。ささらに， $\mathrm{ZnO}$ の励起子分子結合エネルギーが $15 \mathrm{meV}$ と比較的大きいことも魅力的である. 励起子分 子を利用することにより, 超低しきい值のレーザー発振 が期待されるためである ${ }^{8,9)}$.

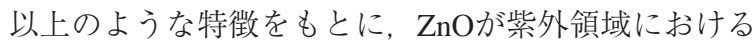
LEDやレーザー等の発光デバイス材料として注目される ようになった。折しも，GaN系のLEDが急速に進歩した 時代であったが，インジウム (In)を添加したInGaNに生 じる励起子の局在効果が高効率の発光をもたらす理由で あることが明らかになり ${ }^{10)}, 400 \mathrm{~nm}$ 以下の波長領域にお ける発光効率が急激に低下することから， $\mathrm{ZnO}$ は紫外領 域の発光デバイスとしてより有望であると考えられたの である。とくに注目されたのが紫外発光をもとに蛍光体 を励起し, 色純度に優れた白色発光を得るという白色 LEDとしての応用である。その後, GaN系LEDの高効率 化，短波長化が進んだが，まだ紫外領域での発光効率が 十分でなく，デバイスにかかるコストも決して安くない ことから， $\mathrm{ZnO}$ の応用でここに突破口を開けることがで 
Table 1 Crystal structures and several fundamental physical parameters of $\mathrm{ZnO}$ and related oxide materials, comparing to non-oxide semiconductors.

\begin{tabular}{|c|c|c|c|c|c|c|c|}
\hline & $\mathrm{Si}$ & GaAs & $\mathrm{SiC}$ & $\mathrm{GaN}$ & $\mathrm{ZnO}$ & $\mathrm{MgO}$ & $\mathrm{CdO}$ \\
\hline crystal structure* & $\mathrm{D}$ & $\mathrm{Z}$ & $\mathrm{W}$ & $\mathrm{W}$ & $\mathrm{W}$ & $\mathrm{R}$ & $\mathrm{R}$ \\
\hline $\begin{array}{c}\text { bandgap } \\
{[\mathrm{eV}]}\end{array}$ & 1.1 & 1.4 & 3.3 & 3.4 & 3.4 & & \\
\hline $\begin{array}{c}\text { lattice constants } \\
{[\AA]}\end{array}$ & 5.43095 & 5.6533 & $\begin{array}{l}a=3.086 \\
c=15.117\end{array}$ & $\begin{array}{l}a=3.189 \\
c=5.185\end{array}$ & $\begin{array}{l}a=3.250 \\
c=5.2707\end{array}$ & & \\
\hline $\begin{array}{c}\text { bond length } \\
{[\AA]}\end{array}$ & 2.35 & 2.45 & 1.89 & 1.95 & 1.99 & 2.35 & 2.11 \\
\hline $\begin{array}{c}\text { exciton binding } \\
\text { energy } \\
{[\mathrm{meV}]}\end{array}$ & & 4 & & 25 & 60 & & \\
\hline $\begin{array}{c}\text { biexciton binding } \\
\text { energy } \\
{[\mathrm{meV}]} \\
\end{array}$ & & & & 5.6 & 15 & & \\
\hline $\begin{array}{c}\text { mobility (bulk) } \\
{\left[\mathrm{cm}^{2} / \mathrm{Vs}\right]}\end{array}$ & 1500 & 6500 & 1000 & 900 & 300 & & \\
\hline $\begin{array}{c}\text { saturation electron } \\
\text { mobility } \\
{\left[\times 10^{7} \mathrm{~cm} / \mathrm{s}\right]}\end{array}$ & 1.0 & 1.3 & 2.0 & 2.7 & 3.0 & & \\
\hline
\end{tabular}

*D=diamond, $\mathrm{W}=$ wurtzite, $\mathrm{Z}=$ zincblende, $\mathrm{R}=$ rock salt

きるかという点が, 今後注目すべきことがらである.

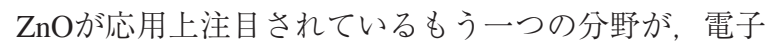
デバイスである。 Table 1に示したように, $\mathrm{ZnO}$ 飽和電 子速度は比較的大きいものと期待されている ${ }^{11)}$ 。これを 活かした超高速電子デバイスへの応用を目指す動きも活 発である。

Table 1に記したように, $\mathrm{ZnO}$ は六方晶の結晶構造を持 つ. その格子定数は, 同じ六方晶構造を持つ $\mathrm{GaN}$ それ

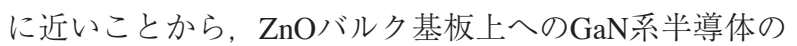
成長 ${ }^{12)}, \mathrm{GaN}$ を゙ッファ層とした $\mathrm{ZnO}$ の成長 ${ }^{13,14)}, \mathrm{GaN}$ 系発光デバイスの上部透明電極としての $\mathrm{ZnO}$ の利用 ${ }^{15)}$, 等の報告がある。今後も両者の融合による新しいデバイ スへの展開が期待できるように思われる.

\section{ZnOベース混晶の基礎物性}

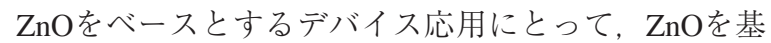
礎としたバンドギャップエンジニアリングが不可欠であ る。実際には, $\mathrm{CdO}$ およ゙ $\mathrm{MgO}$ との混晶化により, バン ドギャップエンジニアリングや多層構造の作製が可能で ある ${ }^{16,17)}$. これらの材料の結晶構造および電子物性の基 本パラメータをTable 1に示してある。この混晶系におけ

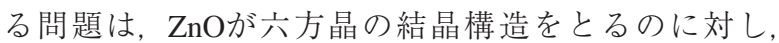
$\mathrm{CdO}$ および $\mathrm{MgO}$ は岩塩構造が安定となることである。そ のため, 混晶化においては, 結晶欠陥や相分離が生じや すく，応用においてはその制御が不可欠である。

Fig. 1 にMgZnOおよび $\mathrm{CdZnO}$ 混晶で観測されたa軸方向 の格子定数を材料のバンドギャップ $(\mathrm{Mg}$ および $\mathrm{Cd}$ 組成 $)$ に対してプロットした結果 ${ }^{17)}$ を示す。同図には, InGaN およびAlGaN混晶についての同様の結果を合わせて記し てある。この図から， $\mathrm{ZnO}$ 系混晶の特徴として，バンド ギャップの変化に対して格子定数の変化が小さい, すな わち一定の格子不整合の範囲でバンドギャップ差の大き いへテロ構造が作製できることがあげられる。
$\mathrm{CdZnO}$ 混晶は, $\mathrm{ZnO}$ に比べてバンドギャップが小さい ため, 青色発光層としての機能を持つ. しかし, $\mathrm{ZnO}$ と $\mathrm{CdO}$ は結晶構造の違いに加え，ボンド長も大幅に異なる ため, $\mathrm{Cd}$ の組成が 0.1 を越すと顕著な相分離が生じるこ とが報告されてきた ${ }^{17,18)}$ （しかしプラズマ援用MOCVD 法により， Cd組成比が 0.7 (バンドギャップ $1.8 \mathrm{eV})$ と大 きい六方晶ZnCdOが得られたという報告がある ${ }^{19)}$

他方, $\mathrm{MgZnO}$ 混晶は, $\mathrm{ZnO}$ に比べてバンドギャップ

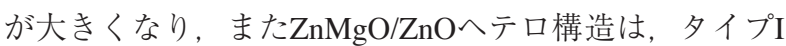
型のバンド接続をとることが示されている ${ }^{20)}$. したがっ て, $\mathrm{MgZnO}$ 混晶は, 紫外発光層としての多重量子井戸 の形成, 紫外発光デバイスのクラッド層, 紫外短波長の

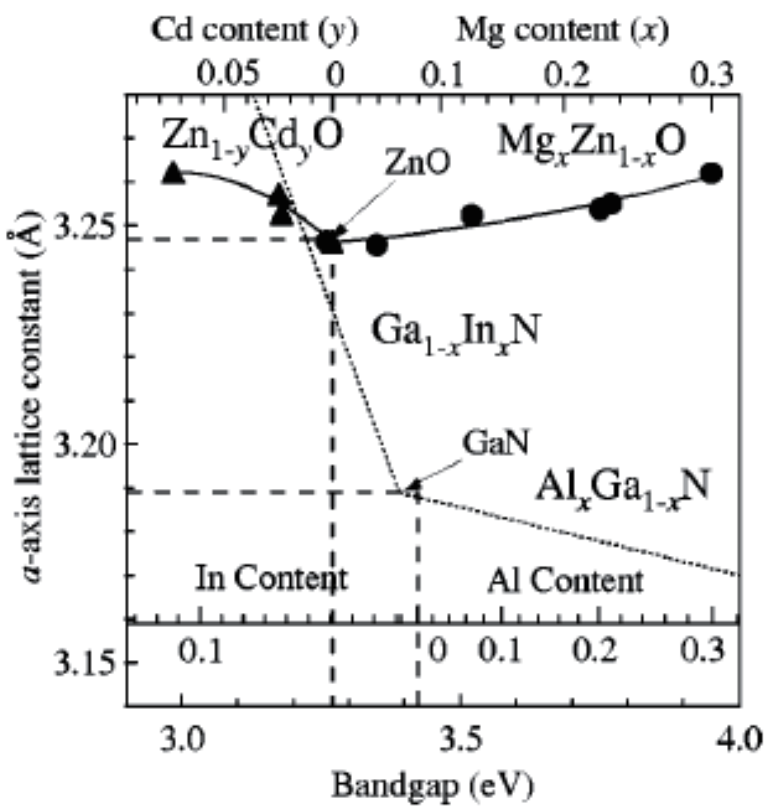

Fig. 1 Lattice constants along the a-axes of $\mathrm{MgZnO}$ and $\mathrm{CdZnO}$ as a function of the bandgap, that is, $\mathrm{Mg}$ and $\mathrm{Cd}$ contents, respectively ${ }^{17)}$. The results are compared with those for $\mathrm{InGaN}$ and $\mathrm{AlGaN}$ against the In and $\mathrm{Al}$ contents. 
光検出層, さらにへテロ接合トランジスタへの応用と いった多くの用途が期待されている. $\mathrm{MgO}$ は岩塩構造 が安定であるが, 六方晶構造を取ることができれば Mg-Oボンド長が1.96 ̊̊と, Zn-Oボンド長の1.99 ̊に近 くなることが予想されている ${ }^{21)}$. したがって，下地層と して高品質のZnOを用いることで結晶構造が六方晶に引 き达まれやすいものと期待される。実際，最近になって $\mathrm{Mg}$ 組成が 0.5 (バンドギャップ $4.4 \mathrm{eV}$ ) と大きい六方晶の 単結晶が得られることが報告され ${ }^{22,23)}$, ソーラブライン ド領域の光検出器22, $\mathrm{MgZnO} / \mathrm{ZnO}$ 界面における二次元 電子ガスの形成 ${ }^{24-26)}$ とトランジスタ ${ }^{27)}$, バイオセンサ ${ }^{28)}$ 等が示されている。さらに, 六方晶 $\mathrm{ZnO}$ の上では極薄膜 の $\mathrm{MgO}$ が六方晶をとり, 六方晶 $\mathrm{MgO} / \mathrm{ZnO}$ 超格子の作製 が可能である ${ }^{29)}$.

\section{4. 結晶成長}

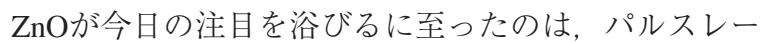
ザ堆積法 (pulsed-laser deposition; PLD) 法による先駆的な 研究がバネとなっている. 単結晶薄膜による半導体の機 能創成という観点で見ると, 酸化物にとっては未知の世 界であった。 $\mathrm{ZnO}$ はともと日焼け止め, 歯科用セメン ト, ベビーパウダーといった応用に用いられていた物質 である。また酸化物薄膜といえば絶縁物，超伝導体，と いった目的に用いられる材料である。つまり，ZnOをは じめとする酸化物はそもそも単結晶により半導体として の機能を利用するという観点からは程遠いものであっ た。したがって，半導体としての応用にとって，制御す ベきパラメータがあまりに多かった。そここでPLD法を利 用し、 コンビナトリアムの手法で各種パラメータを効果 的に最適化して，材料の高品質化が一気に進められ た ${ }^{30)}$. PLD法は大面積基板上への実用的なデバイス作製 技術としては不向きであるという指摘もあるが，材料の 機能を明確化しうるという観点では効果的な成長技術で ある、

実際のデバイス作製技術という点では，分子線エピタ キシ (molecular beam epitaxy; MBE) や有機金属気相エピ タキシ (metalorganic chemical vapor deposition; MOCVD) は有益な方法である。 $\mathrm{ZnO}$ の結晶成長では, 蒸気圧の高 い酸素が空孔を生じることが大きな問題であるため, 酸 素の原料や供給方法が重要なポイントである.MBEで は一般に $\mathrm{O}_{2}$ ガスをプラズマ化して供給する方法が用い られ，原子状酸素が十分に供給されることが重要と考え られている ら $^{31}$ 。また, より活性な酸化種として, $\mathrm{H}_{2} \mathrm{O}^{32,33)}$ やオゾン ${ }^{34)}$ を原料とする試みもある. MOCVDで は, 酸素原料として $\mathrm{O}_{2}$ や $\mathrm{H}_{2} \mathrm{O}$ が古くから用いられている ものの, 反応性が高すぎるため気相での前駆反応を起こ しやすいという問題 ${ }^{35)}$ がある。他方前駆反応をある程度 抑えられる原料としては, テトラヒドロフラン (tetrahydrofran; $\left.\mathrm{C}_{4} \mathrm{H}_{8} \mathrm{O}\right)^{36)}$ ， ターシャリブチルアルコール (tertiarybutylalcohol; $t$-BuOH) ${ }^{37)}$, 亜酸化窒素(nitrous oxide; $\left.\mathrm{N}_{2} \mathrm{O}\right)^{38,39)}$, 二酸化窒素 (nitrogen dioxide; $\left.\mathrm{NO}_{2}\right)^{40)}$ な どが試みられているが, 原料の純度が不十分という懸念
がある。また，プラズマ励起を用いた低温成長も試みら れている41).

さて, $\mathrm{ZnO}$ の応用としてLEDといった大量生産を目指 す観点に立てば，MOCVDのような気相成長技術が鍵に なると思われる。一方，酸化物であるということは，他 の化合物半導体で問題となる酸素の混入は重く考える必 要がない，そこで，Znの原料である有機亚鉛を安全な 原料で代替できれば, 成長コストの大幅な低減を図りう ることが期待される。

この観点で，われわれはミストCVD法の応用に注目 している。この技術は，金属原料として水やアルコール 溶媒に可溶なものを選び，溶液に超音波を印加して生成 したミスト(溶液が直径 $2-3 \mu \mathrm{m}$ の微粒子になったもの) をキャリアガスで基板上へ送り成長反応を起こすもので ある。ミストCVD法は, 誘電体薄膜 ${ }^{22}$ や $\mathrm{ZnO}$ 透明導電 膜 ${ }^{43)}$ の成膜に用いられてきたが, これを単結晶薄膜の成 長に利用しようとしたものである。Fig. 2に， $\mathrm{ZnO}$ 単結 晶基板上に成長した $\mathrm{ZnO}$ 薄膜の表面モフォロジを示 す44)。基板のオフ角が小さい場合には，段差 $0.26 \mathrm{~nm}(1$ 分子層に相当)を持つステップ・テラス構造が見られ る. 基板のオフ角が大きい場合にはステップ・バンチン グが生じてステップ高さは1.04 nm(4分子層に相当)にな るが，やはり明確なステップ・テラス構造を持つ。この ように，この技術によって，MOCVDでも困難なステッ プ・フロー成長が実現したことを示している，また，電 気的にもCVD技術としては高い移動度が得られてい る ${ }^{45)}$ 。このように, 安全・安心で省エネルギー, 低コス 卜の成長技術がZnOの特徴を活かした実用化を支えるこ とが大いに期待される.
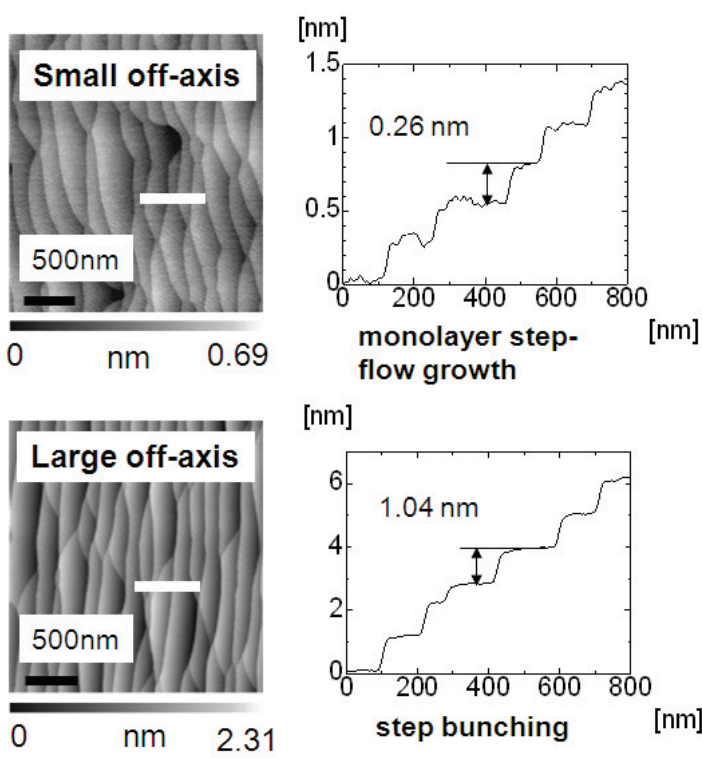

[nm]

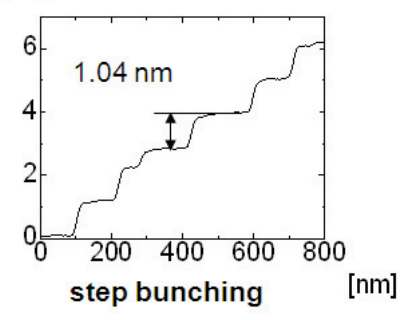

Fig. 2 Surface AFM images of the $\mathrm{ZnO}$ epilayers homoepitaxially grown on $\mathrm{ZnO}$ substrates ${ }^{44)}$. The stepterrace structure showing one monolayer step height $(0.26 \mathrm{~nm})$ was seen on small off-axis substrates. On large off-axis substrates step bunching occurred and the step height became $1.04 \mathrm{~nm}$, corresponding to four layers. 


\section{5. 発光デバイスに向けた取り組み}

\section{1 高品質薄膜の育成}

当初は基板としてc面サファイアが用いられることが 多く，基板との格子不整合から生じる欠陥の低減や成長 層の極性制御 $(\mathrm{ZnO}$ は表面がZn面になる場合とO面にな る場合とがある)が大きな課題であった。 また, 蒸気圧 の高い酸素が空孔を生成しやすいという問題もあった。

MBEの研究初期には, 酸素空孔や不純物に起因して, アンドープでの残留キャリア密度が $10^{19} \mathrm{~cm}^{-3} に$ 及んでい

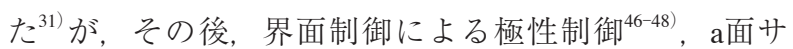
ファイア基板の利用 ${ }^{49)}$ ，等による高品質化が進んだ。ま た, $\mathrm{ZnO}$ とほほ格子整合する $\mathrm{ScAlMgO}_{4}(\mathrm{SCAM})$ 基板の 利用 ${ }^{50)}$, さらにZnO薄膜の研究と並行して開発が進んだ $\mathrm{ZnO}$ 基板を利用したホモエピタキシャル成長 ${ }^{51)} に よ り ，$ 結晶の品質が向上して, 残留キャリア密度 $2.2 \times 10^{16} \mathrm{~cm}^{-3}$, 移動度 $158 \mathrm{~cm}^{2} / \mathrm{Vs}$ という值が得られている ${ }^{51)}$.

$\mathrm{MgZnO}$ は光デバイスの閉じ込め層としての役割から, その高品質化は光デバイス実現に不可欠である. $\mathrm{Mg}$ の 混入により結晶性が劣化するという傾向が多く報告され ているが, 逆に発光効率が増加し, これがInGaNと同様 の励起子局在効果と考察されている ${ }^{52)}$ のは興味深い。 ま た，最近になって $\mathrm{ZnO}$ 基板上のホモエピタキシャル成長 により，光学特性に優れ残留キャリア密度が $10^{15} \mathrm{~cm}^{-3}$ 以 下という $\mathrm{MgZnO}$ が $\mathrm{Mg}$ 組成 $0 \sim 0.39$ の範囲で得られたとい う報告がある

これら高品質薄膜のベストな結果はPLD法とMBE法 により得られており, 現状でCVD系の $\mathrm{ZnO}$ 薄膜は品質的 にこれらに及ばない。デバイス応用への実用技術として はCVD法の開発が必要であると思われるが，後述のp型 ドーピングを含めZnOはまだ材料探索の部分が多く残さ れていることから， $\mathrm{ZnO}$ の特質を見極める点でPLD法と MBE法が中心的な役割を果たして行くものと思われ る.

\section{2 多層構造の成長}

$\mathrm{ZnMgO}$ は, Fig. 1に示したようにZnOとの格子定数差 が小さいため, 広い $\mathrm{Mg}$ 組成で基板とコヒーレントな成 長が可能で53)，ZnOをべースとした各種多層構造への応 用が期待される. $\mathrm{MgZnO} / \mathrm{ZnO}$ 界面における二次元電子 ガスの形成とその高移動度を示す結果 ${ }^{24-26)}$ から, 急峻性 に優れ欠陥の少ない界面が形成可能といえよう。また， $\mathrm{MgZnO} / \mathrm{ZnO}$ 超格子において, $\mathrm{ZnO}$ に比べ励起子結合工 ネルギーが増加する結果もあり ${ }^{55)}$, 光デバイスに向けた 素養は十分と考えられる。

\section{$5.3 \mathrm{p}$ 型伝導の制御と発光デバイス}

$\mathrm{ZnO}$ の光デバイス応用にとって, $\mathrm{p}$ 型伝導性制御が最 大の課題である。p型ZnOが得られたという論文は多い が，それが光デバイスにつながっている結果を示すもの は多くない走6-59)。これらの中で，Asドーピングによる $10^{16}-10^{17} \mathrm{~cm}^{-3}$ のp型伝導の実現と室温・パルス電流下で レーザー発振を示唆する結果が得られていることは興味
深い57)。東北大学/ロームのグループは，PLD法による 温度変調法による $10^{16} \mathrm{~cm}^{-3}$ 以上のp型ZnOを得て青色LED の実現を報告した ${ }^{59)}$ が，その後MBEでNドーピングによ る $\mathrm{MgZnO} / \mathrm{ZnO}$ ダブルヘテロ構造LEDの382 nm紫外光発 光に成功している3)。これは上で述べてきたように，格 子整合系の多層構造と残留不純物の少ない高品質薄膜, さらに急峻なへテロ構造の形成という，これまでの化合 物半導体光デバイスのマイルストンを踏まえることに よって得られた結果である。その意味で，現状における

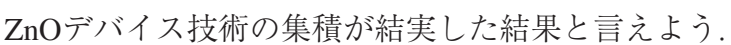

\section{4 他の光・電子デバイスへの応用}

受光デバイスは必ずしもpn接合が必要ではないことか ら, ショットキー型 $\mathrm{MgZnO}$ 光検出器の研究が行われて いる ${ }^{60)} . \mathrm{Mg}$ 組成によって検出光の波長を変化させるこ とができ，六方晶を保つ限界と思われる高 $\mathrm{Mg}$ 組成によ れば, 自然光の影響を受けないソーラブラインド深紫外 光検出器を得ることが可能である。 $\mathrm{ZnO}$ のトランジス夕 は実際に高い飽和移動度を活かすことができるのかとい う実証には至っていないが，バイオセンサへの応用 ${ }^{28}$ は，環境に優しい材料の特性を活かした分野であるとい えよう。また, $\mathrm{ZnO} の$ 室温強磁性の可能性を踏まえ ${ }^{61)}$, スピントランジス夕を目指す動きもある ${ }^{62)}$. 今後, $\mathrm{ZnO}$ のバンドギャップエンジニアリングをもとに，多くのデ バイスへの挑戦が期待されるところである.

\section{6. 酸化物半導体エレクトロニクスへの波及効果}

単結晶の半導体デバイスを目指すという観点での $\mathrm{ZnO}$ の研究は大きな進展を見せたが, 残念なことに実際のデ バイスとして開花するには至っていない，今後どうなる のか, という点に関しては，肯定的な意見もあれば否定 的な意見もある。一方で， $\mathrm{ZnO}$ に関する一連の研究進展 が, 酸化物半導体単結晶薄膜. 多層構造を活かしたデバ イス応用という新たな挑戦的分野を拡げるという波及効 果をもたらしたことは特筆すべきである。

酸化物には多くの種類があり，磁性や圧電性を含めた 多様な機能を持つ。また，多くの酸化物は安定で安全な 材料である。このことから, 酸化物半導体を用い, 原

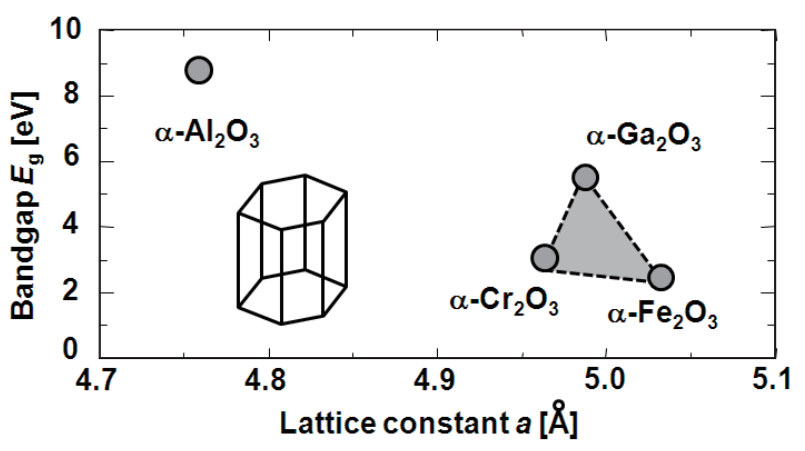

Fig. 3 Bandgap and lattice constants of several corundum-structured oxide thin films. Alloys or multilayer structures of $\mathrm{Ga}_{2} \mathrm{O}_{3}-\mathrm{Cr}_{2} \mathrm{O}_{3}-\mathrm{Fe}_{2} \mathrm{O}_{3}$ on sapphire substrates may be a candidate of new functional materials $^{67)}$. 
料, 成長, 廃棄を含めたプロセスで省エネルギー化を実 現し，かつ新規な機能を持つデバイスを目指すという動 きが強くなった。具体的には，酸化ガリウム $\left(\mathrm{Ga}_{2} \mathrm{O}_{3}\right)^{63)}$, 酸化スズ $\left(\mathrm{SnO}_{2}\right)^{64,65)}$ ，酸化インジウム $\left(\mathrm{In}_{2} \mathrm{O}_{3}\right)^{66)}$ などが注 目されている。また，サファイア $\left(\mathrm{Al}_{2} \mathrm{O}_{3}\right)$ と同じコラン ダム型の結晶を持つ酸化物として, Fig. 3のように $\mathrm{Ga}_{2} \mathrm{O}_{3}, \mathrm{Cr}_{2} \mathrm{O}_{3}, \mathrm{Fe}_{2} \mathrm{O}_{3}$ と性質が大きく異なる材料があり, これらの混晶化や多層化による機能の創成も期待される ようになった ${ }^{67)}$. $\mathrm{ZnO}$ に限らず，このような広い意味で の酸化物半導体の進展に期待したい.

\section{7. まとめ}

$\mathrm{ZnOを}$ 用いた紫外光デバイスの実用化の可能性はいか がなものか，という質問をいただくことが多い. 決め手 はp型伝導の制御であることはまず間違いなく，これが 達成されればLEDやレーザーにつながってゆくであろう ことは，ZnSeやGaNの例を見ても十分予想される。ただ し, $\mathrm{ZnSe}$ の場合はプラズマ化窒素ドーピング, GaNの場 合は熱アニールといった新しい技術の開発が $\mathrm{p}$ 型伝導の 制御につながったことを考えると, $\mathrm{ZnO}$ 場合にも何か ブレークスルーを与える技術があるのかもしれない。こ れまでのZnO光デバイスに向けた研究経過を見ると，基 板との格子整合による高品質化，へテロ界面の形成，残 留キャリア密度の低減, といった半導体デバイスに共通 するプロセスで着実な成果が上がっている。酸化物とい う新しい材料ゆえの問題もあると思われるが, 今後地道 で着実な研究進展により， $\mathrm{ZnO}$ の魅力ある物性を活かし たデバイス創成につながることを大いに期待したい。ま

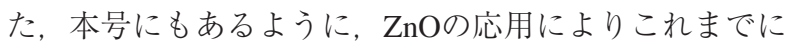
ない観点での新規物性が発現しており，デバイス応用と しての拡がりを見せるものと思われる。あわせて， ZnO から波及した酸化物半導体の進展も今後重要である.

本稿は限られた頁の範囲で大きな題目を取り上げたこ ともあり，参考文献の紹介に注力して内容的に及ばない 点も多いと思われる。これまで多くの方がZnOの物性に ついてまとめていられるため ${ }^{11,68-70)}$, そちらもぜひご参 照をいただきたい。

\section{参考文献}

1) F. H. Nicoll: Appl. Phys. Lett. 9 (1966) 13

2) S. Iwai and S. Namba: Appl. Phys. Lett. 16 (1970) 354

3) K. Nakahara, S. Akasaka, H. Yuji, K. Tamura, T. Fujii, Y. Nishimoto, D. Takamizu, A. Sasaki, T. Tanabe, H. Takasu, H. Amaike, T. Onuma, S. F. Chichibu, A. Tsukazaki, A. Ohtomo, and M. Kawasaki: Appl. Phys. Lett. 97 (2010) 013501.

4) I. Suemune, K. Yoshida, H. Kumano, T. Tawara, A. Ueta, and S. Tanaka: J. Cryst. Growth 248 (2003) 301.

5) D. M. Bagnall, Y. F. Chen, Z. Zhu, T. Yao, M. Y. Shen, and T. Goto: Appl. Phys. Lett. 73 (1998) 1038.

6) Z. K. Tang, G. K. L. Wang, P. Yu, M. Kawasaki, A. Ohtomo, H. Koinuma, and Y. Segawa: Appl. Phys. Lett. 72 (1998) 3270.

7) A. Ohtomo, K. Tamura, M. Kawasaki, T. Makino, Y. Segawa, Z. K. Tang, G. K. L. Wong, Y. Matsumoto, and H. Koinuma: Appl. Phys. Lett. 77 (2000) 2204.

8）塩谷繁雄：固体物理 30 (1995) 24.

9）菅原充：電子情報通信学会技術報告, OPE96-140/
LQE96-138 (1997).

10) Y. Narukawa, Y. Kawakami, M. Funato. S. Fujita, S. Fujita, and S. Nakamura: Appl. Phys. Lett. 70 (1997) 981.

11) 仁木栄, 反保衆志, 柴田 肇: 応用物理 77 (2008) 500.

12) A. Kobayashi, S. Kawano, K. Ueno, J. Ohta, H. Fujioka, H. Amanai, S. Nagao, and H. Horie: Appl. Phys. Lett. 91 (2007) 191905.

13) R. D. Vispute, V. Talyansky, S. Choopun, R. P. Sharma, T. Venkatesan, M. He, X. Tang, J. B. Halpern, M. G. Spencer, Y. X. Li, L. G. Salamanca-Riba, A. A. Iliadis, and K. A. Jones: Appl. Phys. Lett. 73 (1998) 348.

14) Ya. I. Alivov, J. E. Van Nostrand, D. C. Look, M. V. Chukichev, and B. M. Ataev: Appl. Phys. Lett. 83 (2003) 2943.

15) K. Nakahara, K. Tamura, M. Sakai, D. Nakagawa, N. Ito, M. Sonobe, H. Takasu, H. Tampo, P. Fons, K. Matsubara, K. Iwata, A. Yamada, and S. Niki: Jpn. J. Appl. Phys. 43 (2004) L180.

16) A. Ohtomo, M. Kawasaki, T. Koida, K. Masubuchi, H. Koinuma, Y. Sakurai, Y. Yoshida, T. Yasuda, and Y. Segawa: Appl. Phys. Lett. 72 (1998) 2466.

17) T. Makino, Y. Segawa, M. Kawasaki, A. Ohtomo, R. Shiroki, K. Tamura, T. Yasuda, and H. Koinuma: Appl. Phys. Lett. 78 (2001) 1237.

18) K. Sakurai, T. Kubo, D. kajita, T. Tanabe, H. Takasu, Sz. Fujita, and Sg. Fujita: Jpn. J. Appl. Phys. 39 (2000) L1146.

19) T. Ohashi, K. Yamamoto, A. Nakamura, T. Aoki, and J. Temmyo: Jpn. J. Appl. Phys. 46 (2007) 2516.

20) T. Makino, C. H. Chia, Nguen T. Tuan, Y. Segawa, M. Kawasaki, A. Ohtomo, K. Tamura, and H. Koinuma: Appl. Phys. Lett. 77 (2000) 1632 .

21) W. R. L. Lambrecht, S. Limpijumnong, and B. Segall: MRS Internet J. Nitride Semicond. Res. 4S1. (1999) G6.8.

22) T. Takagi, H. Tanaka, Sz. Fujita, and Sg. Fujita: Jpn. J. Appl. Phys. 42 (2003) L401.

23) A. Ohtomo and T. tsukazaki: Semicond. Sci. \& Tehnol. 72 (2005) S1.

24) M. Yano, K. Hashimoto, K. Fujimoto, K. Koike, S. Sasa, M. Inoue, Y. Uetsuji, T. Ohnishi, and K. Inaba: J. Crystal Growth 301-302 (2007) 353.

25) H. Tampo, K. Matsubara, A. Yamada, H. Shibata, P. Fons, M. Yamagata, H. Kanie, and S. Niki: J. Crystal Growth 301-302 (2007) 358.

26) A. Tsukazaki, H. Yuji, S. Akasaka, K. Tamura, K. Nakahara, T. Tanabe, H. Takasu, A. Ohtomo, and M. Kawasaki: Appl. Phys. Express 1 (2008) 055004.

27) T. Hayafuji, M. Kawasaki, K. Koike, M. Yano, and M. Inoue: IEEE Elec. Device Lett. 28 (2007) 543.

28) K. Koike, D. Takagi, M. Hashimoto, T. Hashimoto, T. Inoue, K. Ogata, S. Sasa, M. Inoue, and M. Yano: Jpn. J. Appl. Phys. 48 (2009) 04C081.

29) H. Tanaka, S. Fujita, and S. Fujita: Appl. Phys. Lett. 86 (2005) 192911

30) Y. Matsumoto, M. Murakami, Z. Jin, A. Ohtomo, M. Lippma, M. Kawasaki, and H. Koinuma: Jpn. J. Appl. Phys. 38 (1999) L603.

31) M. A. L. Johnson, S. Fujita, W. H. Rowland, Jr., W. C. Hughes, J. W. Cook, Jr., and J. F. Schetzina: J. Electron. Mater. 25 (1996) 855 .

32) A. B. M. A. Ashrafi, I. Suemune, and H. Kumano: Jpn. J. Appl. Phys. 41 (2002) 2851.

33) T. Terasako, Y. Ishiko, K. Saeki, S. Yudate, and S. Shirakata: J. Cryst. Growth 298 (2007) 481.

34) Y. W. Heo, K. Ip, S. J. Pearton, D. P. Norton, and J. D. Budai: Appl. Surf. Sci. 252 (2006) 7442.

35) C. K. Lau, S. K. Tiku, and K. M. Lakin: J. Electrochem. Soc. 127 (1980) 1843

36) P. J. Wright, R. J. Griffiths, and B. Cockayne: J. Cryst. Growth 66 (1984) 26.

37) B. Hahn, G. Heindel, E. Pschorr-Schoberer, and W. Gebhardt: Semicond. Sci. Technol. 13 (1998) 788

38) K. Haga, M. Kamidaira, Y. Kashiwaba, T. Sekiguchi, and H. Watanabe: J. Cryst. Growth 214/215 (2000) 77.

39) K. Ogata, K. Maejima, S. Fujita, and Sg. Fujita: J. Electron. Mater. 30 (2001) 659.

40) S. Fujita, K. Maejima, S.-W. Kim, K. Ogata, and Sg. Fujita: Proc. 10th Int. Ceramics Congress, Florence, Italy (Techina Srl., 2003) 
p.65.

41) M. Shimizu, H. Kamei, M. Tanizawa, T. Shiosaki, and A. Kawabata: J. Cryst. Growth 89 (1988) 365.

42) S. Kawasaki, S. Motoyama, T. Tatsuta, O. Tsuji, S. Okamura, and T. Shiosaki: Jpn. J. Appl. Phys. 43 (2004) 6562.

43）川原村敏幸, 西中浩之, 藤田 静雄: 材料 57 (2008) 481 .

44) H. Nishinaka and S. Fujita: J. Cryst. Growth 310 (2008) 5007.

45) H. Nishinaka, Y. Kamada, N. Kameyama, and S. Fujita: Jpn. J. Appl. Phys. 48 (2009) 121103.

46) H. Kato, K. Miyamoto, M. Sano, and T. Yao: Appl. Phys. Lett. 84 (2004) 4562.

47) X. Wang, Y. Tomita, O.-H. Roh, M. Ohsugi, S.-B. Che, Y. Ishitani, and A. Yoshikawa: Appl. Phys. Lett. 86 (2005) 011921

48) Z. X. Mei, X. L. Du, Y. Wang, M. J. Ying, Z. Q. Zeng, H. Zheng, J. F. Jia, Q. K. Xue, and Z. Zhang: Appl. Phys. Lett. 86 (2005) 112111.

49) P. Fons, K. Iwata, A. Yamada, K. Matsubara, S. Niki, K. Nakahara, T. Tanabe, and H. Takasu: Appl. Phys. Lett. 77 (2000) 1801.

50) A. Tsukazaki, A. Ohtomo, S. Yoshida, M. Kawasaki, C. H. Chia, T. Makino, Y. Segawa, T. Koida, S. F. Chichibu, and H. Koinuma: Appl. Phys. Lett. 83 (2003) 2784.

51) H. Kato, M. Sano, K. Miyamoto, and T. Yao: Jpn. J. Appl. Phys. 42 (2003) L1002.

52) H. Shibata, H. Tampo, K. Matsubara, A. Yamada, K. Sakurai, S. Ishizuka, and S. Niki: Appl. Phys. Lett. 90 (2007) 124104.

53) Y. Nishimoto, K. Nakahara, D. Takamizu, A. Sasaki, K. Tamura, S. Akasaka, H. Yuji, T. Fujii, T. Tanabe, H. Takasu, A. Tsukazaki, A. Ohtomo, T. Onuma, S. F. Chichibu, and M. Kawasaki: Appl. Phys. Express 1 (2008) 091202.

54) S. Akasaka, K. Nakahara, A. Tsukazaki, A. Ohtomo, and M. Kawasaki; Appl. Phys. Express 3 (2010) 071101.

55) T. Makino, Y. Segawa, M. Kawasaki, and H. Koinuma: Semicond. Sci. Technol. 20 (2005) S78.
56) Z. P. Wei, Y. M. Lu, D. Z. Shen, Z. Z. Zhang, B. Yao, B. H. Li, J. Y. Zhang, D. X. Zhao, X. W. Fan, and Z. K. Tang: Appl. Phys. Lett. 90 (2007) 042113.

57) Y. R. Ryu, T. S. Lee, J. A. Lubguban, A. B. Corman, H. W. White, J. H. Leem, M. S. Han, C. J. Youn, and W. J. Kim: Appl. Phys. Lett. 88 (2006) 052103.

58) W. Z. Xu, Z. Z. Ye, Y. J. Zeng, L. P. Zhu, B. H. Zhao, L. Jiang, J. G. Lu, H. P. He, and S. B. Zhang: Appl. Phys. Lett. 88 (2006) 173506.

59) A. Tsukazaki, M. Kubota, A. Ohtomo, T. Onuma, K. Ohtani, H. Ono, S. F. Chichibu, and M. Kawasaki: Jpn. J. Appl. Phys. 44 (2005) L643.

60) M. Nakano, T. Makino, A. Tsukazaki, K. Ueno, A. Ohtomo, T. Fukumura, H. Yuji, Y. Nishimoto, S. Akasaka, D. Takamizu, K. Nakahara, T. Tanabe, A. Kamisawa, and M. Kawasaki: Appl. Phys. Express 1 (2008) 121201.

61) T. Dietl, H. Ohno, F . Matsukura, J . Cibert, and D. Ferrand: Science 287 (2000) 1019.

62) T. Edahiro, N. Fujimura, and T. Ito: J. Appl. Phys. 93 (2003) 7673.

63) T. Oshima, T. Okuno, N. Arai, N. Suzuki, H. Hino, and S. Fujita: Jpn. J. Appl. Phys. 48 (2009) 011605.

64) M. E. White, M. Y. Tsai, F. Wu, and J. S. Speck: J. Vac. Sci. Technol. A 26 (2008) 1300.

65) T. Oshima, T. Okuno, and S. Fujita: Jpn. J. Appl. Phys. 48 (2009) 120207.

66) Z.X. Mei, Y. Wang, X. L. Du, Z. Q. Zeng, M. J. Ying, H. Zheng, J. F. Jia, Q. K. Xue, and Z. Zhang: J. Cryst. Growth 289 (2006) 686

67) K. Kaneko, T. Nomura, and S. Fujita: Phys. Stat. Solidi (c) 7 (2010) 2467

68）応用物理学会第42回応用物理学会スクールテキスト。

69) 工業材料 56 No.10 (2008).

70) 高橋 清監修：ワイドギャップ半導体光・電子デバイス（森 北出版, 2006). 